\title{
Mass changes of Southern and Northern Inylchek Glacier, Central Tian Shan, Kyrgyzstan, during $\sim 1975$ and 2007 derived from remote sensing data
}

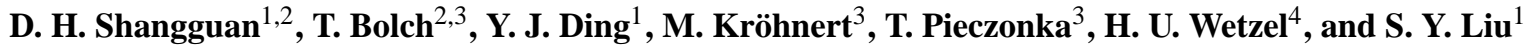 \\ ${ }^{1}$ State Key Laboratory of Cryospheric Science, Cold \& Arid Regions Environmental \& Engineering Research Institute, \\ Chinese Academy of Sciences, Lanzhou 730000, China \\ ${ }^{2}$ Department of Geography, University of Zurich, 8057 Zurich, Switzerland \\ ${ }^{3}$ Institute for Cartography, Technische Universität Dresden, 01069 Dresden, Germany \\ ${ }^{4}$ GFZ German Research Centre for Geosciences, Potsdam, Germany
}

Correspondence to: D. H. Shangguan (dhguan@lzb.ac.cn)

Received: 31 March 2014 - Published in The Cryosphere Discuss.: 21 May 2014

Revised: 15 February 2015 - Accepted: 3 March 2015 - Published: 15 April 2015

\begin{abstract}
Glacier melt is an essential source of freshwater for the arid regions surrounding the Tian Shan. However, the knowledge about glacier volume and mass changes over the last decades is limited. In the present study, glacier area, glacier dynamics and mass changes are investigated for the period 1975-2007 for Southern Inylchek Glacier (SIG) and Northern Inylchek Glacier (NIG), the largest glacier system in Central Tian Shan separated by the regularly draining Lake Merzbacher. The area of NIG increased by $2.0 \pm 0.1 \mathrm{~km}^{2}(\sim 1.3 \%)$ in the period $\sim 1975-$ 2007. In contrast, SIG has shrunk continuously in all investigated periods since $\sim 1975$. Velocities of SIG in the central part of the ablation region reached $\sim 100-120 \mathrm{~m} \mathrm{a}^{-1}$ in $2002 / 2003$, which was slightly higher than the average velocity in 2010/2011. The central part of SIG flows mainly towards Lake Merzbacher rather than towards its terminus. The measured velocities at the distal part of the terminus downstream of Lake Merzbacher were below the uncertainty, indicating very low flow with even stagnant parts. Geodetic glacier mass balances have been calculated using multi-temporal digital elevation models from $\mathrm{KH}$ 9 Hexagon (representing the year 1975), SRTM3 (1999), ALOS PRISM (2006) and SPOT-5 high-resolution geometrical (HRG) data (2007). In general, a continuous mass loss for both SIG and NIG could be observed between $\sim 1975$ and 2007. SIG lost mass at a rate of $0.43 \pm 0.10 \mathrm{~m}$ w.e. $\mathrm{a}^{-1}$ and NIG at a rate of $0.25 \pm 0.10$ mw.e. $\mathrm{a}^{-1}$ within the pe-
\end{abstract}

riod 1975-1999. For the period 1999-2007, the highest mass loss of $0.57 \pm 0.46 \mathrm{~m}$ w.e. $\mathrm{a}^{-1}$ was found for NIG, whilst SIG showed a potential moderate mass loss of $0.28 \pm 0.46 \mathrm{~m}$ w.e. $\mathrm{a}^{-1}$. Both glaciers showed a small retreat during this period. Between $\sim 1975$ and 1999, we identified a thickening at the front of NIG with a maximum surface elevation increase of about $150 \mathrm{~m}$ as a consequence of a surge event. In contrast significant thinning $\left(>0.5 \mathrm{~m} \mathrm{a}^{-1}\right)$ and comparatively high velocities close to the dam of Lake Merzbacher were observed for SIG, indicating that Lake Merzbacher enhances glacier mass loss.

\section{Introduction}

Meltwater from snow and ice is an important freshwater resource for the arid regions surrounding the Tian Shan (Sorg et al., 2012). This is especially true for the Tarim Basin in Xinjiang/northwest China, whose main artery, the Tarim River, is considerably nourished by glacial melt (Aizen et al., 2007; Krysanova et al. ,2015; Sorg et al., 2012). The transboundary Aksu River (called Sary-Djaz in Kyrgyzstan), originating in the Kyrgyz part of the Central Tian Shan, is the main tributary of the Tarim and contributes 40-70\% to the overall run-off of the Tarim River (Mao et al., 2004). The run-off of Aksu River has increased during the last decades (Li et al., 2008; Liu et al., 2006; Piao et al., 2012). Shen et al. (2009) estimated that 
$13 \%$ of the annual run-off during 1957-2006 in the Aksu River was due to the glacier imbalance, while Pieczonka and Bolch (2015) estimated an even higher value of $\sim 20 \%$ for the period $\sim 1975-1999$. Reported glacier shrinkage rates were $\sim 3.7 \%$ for the entire Sary-Djaz Basin between 1990 and 2010 (Osmonov et al., 2013) and $\sim 8.7 \%$ for the neighbouring Ak-Shiirak Range for the period 1977-2003 (Aizen et al., 2006). Piezoncka and Bolch (2014) found significant mass loss for a similar region, despite relatively low area loss. Hence, we conclude that the run-off increase of Aksu River is partly due to increased glacier melt. Changes of mass balance can be directly linked to climate change and run-off. Glacier mass balance is traditionally measured in situ. As this work is laborious and most of the glaciers are located in remote and hardly accessible terrain, measurements can only be conducted on site for few glaciers. Several studies have shown that remote-sensing-derived geodetic mass balance estimates are suitable to extend in situ measurements in space and time (e.g. Berthier et al., 2010; Bolch et al., 2011; Gardelle et al., 2013; Paul and Haeberli, 2008) and are even used to calibrate time series of in situ glaciological records (e.g. Zemp et al., 2013).

Glaciers in Central Tian Shan have experienced significant mass loss over recent decades. Aizen et al. (2006) determined a thinning rate of $0.69 \pm 0.37 \mathrm{ma}^{-1}$ (or $0.59 \pm 0.31 \mathrm{mw}$.e. $\mathrm{a}^{-1}$ mass loss, using a density of $850 \mathrm{~kg} \mathrm{~m}^{-3}$ to convert volume to mass changes) for the AkShiirak Massif, the second-largest glacierized massif in the Central Tian Shan. Furthermore, Pieczonka et al. (2013) found a mass loss of $0.42 \pm 0.23 \mathrm{mw}$.e. $\mathrm{a}^{-1}$ using 1976 KH-9 data and the SRTM3 digital elevation model (DEM) for several partially debris-covered glaciers south of Peak Pobeda/Tomur Feng (Pik Pobeda in Russian, Tomur Feng in Chinese and Jengish Choqusu in Kyrgyz). The mass loss in the recent period (1999-2009) was slightly lower.

The Southern Inylchek Glacier (SIG) is the largest glacier in Central Tian Shan and is characterized by a layer of debris altering both rates and spatial patterns of melting. SIG was investigated by field-based methods (ablation measurements; e.g. Hagg et al., 2008) and by remote sensing (velocity measurements; e.g. Li et al., 2013). However, there is still a lack of detailed volume and mass change investigations. In the present study, we used stereo 1974/1976 KH-9 Hexagon, 2006 ALOS PRISM, 2008 SPOT-5 high-resolution geometrical (HRG) data and the SRTM3 DEM from February 2000 to assess the mass change of SIG and NIG. In addition, we investigated glacier dynamics of the glacier and changes in area using Landsat TM/ETM+ and Terra ASTER imagery.

\section{Study region}

Inylchek Glacier is located in the Kumarik Catchment, the headwater of the Aksu-Tarim River catchment between Tomur Feng (7439 m a.s.l., the highest peak of the Tian Shan) and Khan Tengri (6995 ma.s.l.) (Fig. 1). The glacier consists of two branches: the Southern and Northern Inylchek Glacier (SIG and NIG), which formerly had a joined tongue; however, glacier recession led to their separation (Kotlyakov et al., 1997; Lifton et al., 2014). The space between the two tongues was filled by Lake Merzbacher as the tongue from the SIG formed an ice barrier which dammed the meltwater (Glazirin, 2010; Häusler et al., 2011). SIG stretches about $60.5 \mathrm{~km}$ in east-west direction with an area of approximately $500 \mathrm{~km}^{2}$. NIG and SIG together account for $\sim 32 \%$ of the total glacier area of the Sary-Djaz River basin (Osmonov et al., 2013). The equilibrium line altitude (ELA) is located at about $4500 \mathrm{~m}$ a.s.l. (Aizen et al., 2007). Existing velocity measurements of SIG show surface velocities of about $100 \mathrm{~m} \mathrm{a}^{-1}$ for the central part of the ablation region (Li et al., 2013; Nobakht et al., 2014) where the glacier flow is mainly directed towards Lake Merzbacher (Mayer et al., 2008; Nobakht et al., 2014).

The study region is characterized by a semi-continental climate. Precipitation recorded at Tian Shan Station (TS) $(1960-1997)\left(78.2^{\circ} \mathrm{N}, 41.9^{\circ} \mathrm{E}, 3,614 \mathrm{~m}\right.$ a.s.l., Fig. 1) and Koilu Station (K) $(1960-1990)\left(79.0^{\circ} \mathrm{E}, 42.2^{\circ} \mathrm{N}\right.$, $2,800 \mathrm{~m}$ a.s.l., Fig. 1) was $279 \mathrm{~mm} \mathrm{a}^{-1}$ and $311 \mathrm{~mm} \mathrm{a}^{-1}$, respectively (Reyers et al., 2013), with about $75 \%$ of precipitation occurring during summer (May-September). Hence, both SIG and NIG receive a significant amount of the accumulation during summer (Osmonov et al., 2013). No longterm precipitation measurements exist on the glacier itself. However, Aizen et al. (1997) found a positive correlation between annual accumulation measured by stakes at $6148 \mathrm{~m}$ a.s.l. and annual precipitation for TS Station. The mean annual temperature at TS is about $-7.7^{\circ}$, with January being the coldest month $\left(-21.8^{\circ}\right)$ and July the warmest $\left(4.3^{\circ}\right)$ (Osmonov et al., 2013).

\section{Data and methods}

\subsection{Remote sensing data sets}

Declassified KH-9 Hexagon, SPOT-5 HRG, ALOS PRSIM, Terra ASTER, Landsat TM/ETM+ and SRTM3 data were used to obtain information about surface elevation, surface velocity and area extent for both SIG and NIG for different periods (Table 1).

Images from the KH-9 Hexagon mission, which was part of the US Keyhole reconnaissance satellite programme, were declassified in 2002 (Pressel, 2013). A frame camera system was used on a total of 12 missions between 1973 and 1980. The film used for the KH4 mission was the same as for the KH-9 mission and had a resolution of about 85 line pairs $\mathrm{mm}^{-1}$. In our study, we used Hexagon images from mission 1209, flown in November 1974, and mission 1211, flown in January 1976 (in the following we use the mean year $\sim 1975$ for ease of understanding). 


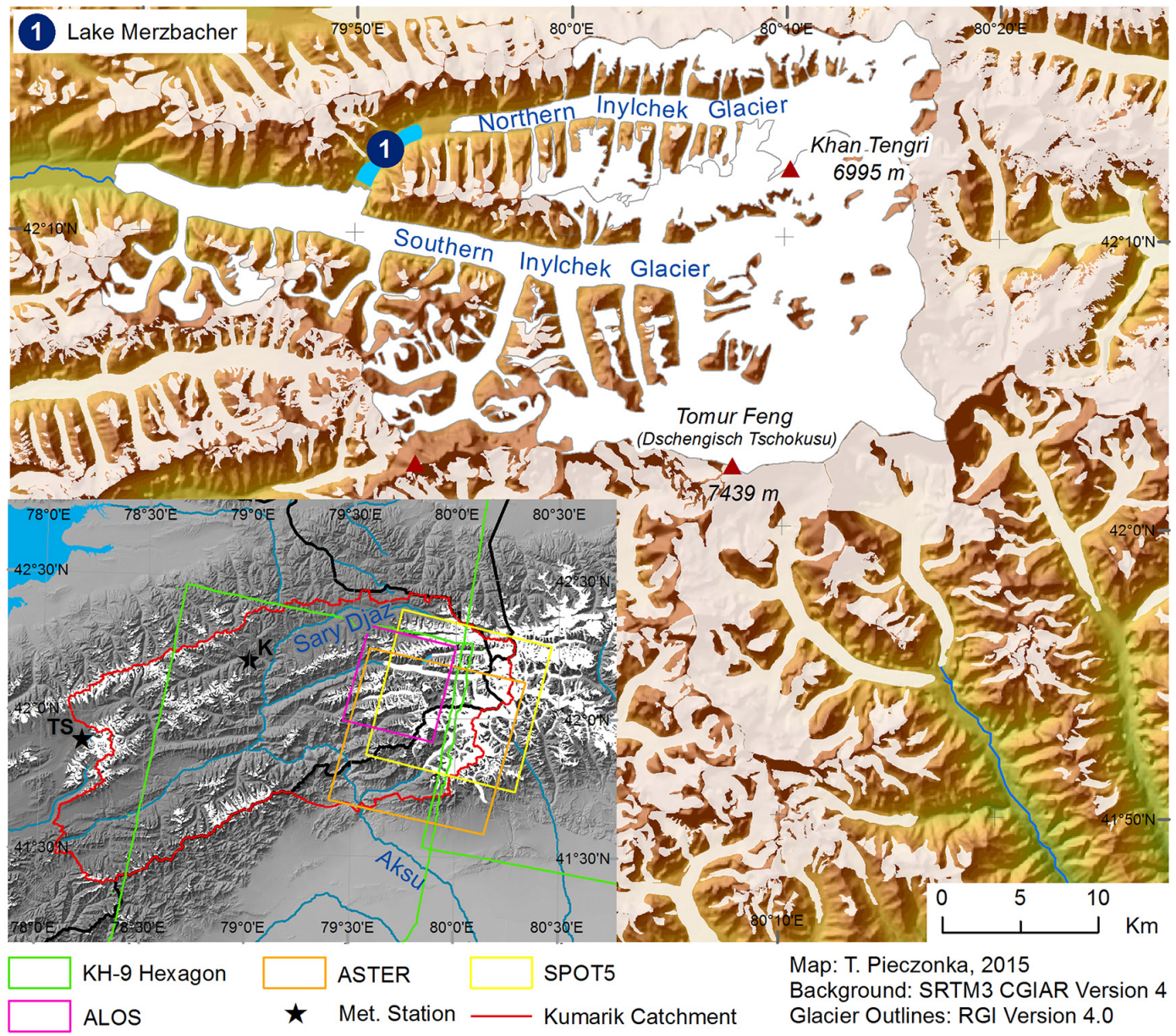

Figure 1. Location and topography of Southern Inylchek Glacier (SIG) and Northern Inylchek Glacier (NIG). TS is Tian Shan Station; K is Koilu Station.

Table 1. List of utilized satellite images and data sources.

\begin{tabular}{|c|c|c|c|c|c|c|}
\hline Satellite & Time & $\begin{array}{l}\text { Pixel size } \\
\text { (nadir, m) }\end{array}$ & $\begin{array}{l}\text { Swatch } \\
(\mathrm{km})\end{array}$ & $B / H$ & $\begin{array}{l}\text { DEM pixel } \\
\text { size }(\mathrm{m})\end{array}$ & $\begin{array}{l}\text { Velocity } \\
\text { image }\end{array}$ \\
\hline ALOS nadir (N) backwards (B) & 8 Oct 2006 & 2.5 & 35 & 0.5 & 10 & - \\
\hline SPOT5 HRG & 5 Feb 2008 & 2.5 & 60 & 0.63 & 10 & - \\
\hline SRTM unfilled finished-B version & Feb 2000 & & $1^{\circ} \times 1^{\circ}($ tile size $)$ & - & 90 & - \\
\hline Landsat ETM+ & 13 Oct 1999 & 15 & 185 & - & - & - \\
\hline Landsat TM & 10 Sep 1990 & 30 & 185 & - & - & - \\
\hline KH-9 Hexagon & 16 Nov 1974 & $6-9$ & $240 \times 120$ & & 25 & - \\
\hline Terra ASTER & 25 Aug 2002 & 15 & 60 & & & Yes \\
\hline Terra ASTER & 28 Aug 2003 & 15 & 60 & & & Yes \\
\hline Landsat TM & 16 Aug 2010 & 30 & 185 & & & Yes \\
\hline Landsat TM & 3 Aug 2011 & 30 & 185 & & & Yes \\
\hline
\end{tabular}

For the year around 2000, the unfilled finished Shuttle Radar Topography Mission (SRTM) data with 3 arcsec resolution (approximately $90 \mathrm{~m}$ ) (USGS, 2006) was used. Yang et al. (2011) and Shortridge et al. (2011) reported an absolute vertical accuracy of the SRTM3 DEM of about $10 \mathrm{~m}$.
However, the accuracy in mountainous terrain is inferior (Gorokhovich et al., 2006; Pieczonka et al., 2011; Surazakov et al., 2006). The original SRTM3 data set has some data voids especially at high and steep elevation regions due to radar shadow and layover effects (Supplement Fig. S1). 
Thus, parts of the accumulation regions are not covered by the SRTM3 DEM. These gaps have been filled in the SRTM3 CGIAR version 4 DEM using auxiliary data (Jarvis et al., 2008). However, the exact time is only known for the original data. The void-filled SRTM3 DEM was used for the orthorectification of ASTER images and the calculation of the glacier hypsometry (Fig. S2). Due to the acquisition in February 2000 and the penetration of the used C-band, the DEM can be seen as representative of the glacier surface as constituted at the end of the 1999 ablation period. However, the penetration of the C-band radar waves needs to be taken into account for volume change calculations as it can range from 1 to $2 \mathrm{~m}$ even on exposed ice and up to $10 \mathrm{~m}$ on dry, cold firn (Gardelle et al., 2012; Rignot et al., 2001).

The SPOT-5 HRG instruments offer across-track stereo images with the viewing angle being adjustable through $\pm 27^{\circ}$ from two different orbits, which are suitable for DEM generation in high mountain areas (Toutin, 2006). Due to the precise onboard measurements of satellite positions and attitudes of the SPOT-5 orbit, each pixel in a SPOT-5 image can be located on the ground with an accuracy of $\pm 25 \mathrm{~m}$ on the $66 \%$ confidence level without additional ground control points (GCPs) (Berthier et al., 2007; Bouillon et al., 2006). Two SPOT-5 HRG images, acquired on 5 February 2008 with an incidence angle of -9.79 and $24.94^{\circ}$ offering a base-toheight ratio $(B / H)$ of about 0.63 , were used for DEM generation (Table 1). The image contrast on the glacier of the utilized images is suitable for DEM generation, but several regions in the SPOT-5 DEM are influenced by cast shadows and were eliminated from the final DEM (Fig. S2).

ALOS was launched in January 2006, carrying the PRISM optical sensor in a triplet mode (i.e. in forward, nadir and backward views in along-track direction) (Takaku et al., 2004). In this study, we used the nadir and backward images (Table 1). The horizontal accuracy of the geometrical model with rational polynomial coefficients (RPCs) (which contains the interior and exterior information) can achieve an accuracy of $6.0 \mathrm{~m}$ and above (or $7.5 \mathrm{~m}$ in horizontal direction and $2.5 \mathrm{~m}$ in vertical direction) without any GCPs (Takaku et al., 2004; Uchiyama et al., 2008). This accuracy can be improved by using additional GCPs.

In addition to the above-mentioned images, we used Landsat TM/ETM+ and Terra ASTER data to investigate the changes in glacier extent and to observe the glacier flow (Table 1). Unfortunately only SIG was covered by the utilized ASTER scenes.

\subsection{Glacier boundary}

The glacier boundaries were manually delineated from Landsat $\mathrm{TM} / \mathrm{ETM}+$, orthorectified panchromatic SPOT-5 and KH-9 images. Debris cover on the tongue of SIG hampered the accurate identification of the glacier margin. However, water outlets at the front of SIG and traces left following the water flow around the tongue are visible in the images.

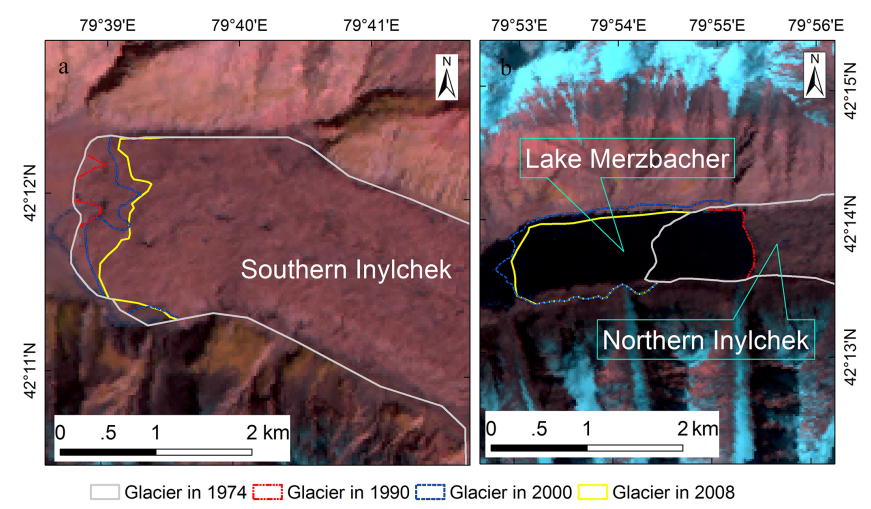

Figure 2. Changes in glacier front position of SIG and NIG between $\sim 1975$ and 2007. The background Landsat TM image was acquired in 1990 .

We identified the lines of the traces surrounding the debriscovered ice as the glacier terminus boundary (Fig. 2a). For NIG, the delineation between the water and debris was used as the terminus boundary of ice (Fig. 2b). The hillshade based on the SRTM3 DEM and the calculated ALOS and Hexagon DEMs provided additional information to detect the glacier boundary. The accuracy of the glacier outlines is strongly influenced by debris cover and different spatial resolutions of the used satellite data sets (Paul et al., 2013). We estimated the uncertainty using a buffer of $10 \mathrm{~m}$ for the KH-9 images and half a pixel for Landsat TM/ETM+ images in the bare-ice region and good snow conditions (cf. Bolch et al., 2010). For the debris-covered parts, a buffer of two pixels was used to evaluate the delineation uncertainty. We assumed that the uncertainty due to image coregistration is captured with the buffer method. Under consideration of the law of error propagation, the final uncertainty $\theta_{\text {change }}$ was calculated using Eq. (1):

$\theta_{\text {change }}=\sqrt{\theta_{\text {period 1 }}^{2}+\theta_{\text {period 2 }}^{2}}$

where $\theta_{\text {period } 1}$ and $\theta_{\text {period } 2}$ represent the uncertainties of the glacier outlines in period 1 and period 2, respectively. The mapping uncertainties vary between 0.3 and $3.7 \%$ (Table 2).

\subsection{Flow velocity of SIG}

To investigate the dynamic behaviour of the SIG, we measured glacier displacement rates using multi-temporal optical satellite image covering a time span of about 1 year. A frequency-based feature tracking (phase correlation) was performed using the EXELIS VIS ENVI add-on COSI-Corr in order to get the horizontal offset of the corresponding image points. For ASTER data a previous subpixel coregistration was performed as described in Leprince et al. (2007) using the gap-filled SRTM3 CGIAR DEM, which was bilinearly resampled to $30 \mathrm{~m}$, as a vertical reference. Landsat level $1 \mathrm{~T}$ data were assumed to be quasi-coregistered because 
Table 2. Uncertainty of glacier delineation (\%).

\begin{tabular}{lrrrr|rrrr}
\hline & \multicolumn{3}{c}{ SIG } & \multicolumn{4}{c}{ NIG } \\
\hline & Landsat & KH-9 & Landsat & SPOT-5 & Landsat & KH-9 & Landsat & SPOT-5 \\
\hline & TM & & ETM+ & & TM & & ETM+ \\
Landsat TM & 2.2 & 2.7 & 2.4 & & 3.1 & 3.7 & 3.4 & \\
KH-9 & & 1.5 & - & 1.6 & & 2.1 & - & 2.1 \\
Landsat ETM+ & & - & 1.0 & 1.0 & & - & 1.5 & 1.6 \\
SPOT-5 & - & & - & 0.3 & - & & - & 0.6 \\
\hline
\end{tabular}

of the same sets of GCPs and vertical references used for orthorectification. On the basis of an expected annual average velocity of SIG of up to $90 \mathrm{~m} \mathrm{a}^{-1}$ (observed in 2003/2004; Mayer et al., 2008) and the images' resolution, the step size was set to four pixels for ASTER and two pixels for Landsat. Hence, both displacement maps have a final resolution of $60 \mathrm{~m}$.

The relative offsets of the coregistered images show the phase difference of the previously Fourier transformed input data and can be estimated by the correlation maximum (Leprince et al., 2007). For the 2010/2011 observation period, offsets in the north-south and east-west-direction were measured with an accuracy of $1 / 7$ pixel using Landsat TM (L1T) data. For the 2002/2003 period, we achieved a precision of $1 / 4$ pixel based on $1 / 25$ pixel coregistered ASTER (L1A) data. A signal-to-noise ratio (SNR) of 0.9 was selected and applied to filter obvious outliers. The reliability of the displacement vectors was assessed by the ratio of the root mean square error (RMSE) and the resolution of the respective input data. Errors caused by clouds, topography and low image contrast have been removed from the matching result. The final uncertainty has been determined to be $3.5 \mathrm{~m} \mathrm{a}^{-1}$ for 2002/2003 and $4.7 \mathrm{~m} \mathrm{a}^{-1}$ for 2010/2011.

\subsection{DEM generation and DEM post-processing}

KH-9, ALOS PRISM and SPOT-5 HRG data were processed by using Leica Photogrammetry Suite (LPS) 2013 with the reference system WGS84 UTM zone $44 \mathrm{~N}$.

For the stereo processing of the KH-9 images, we measured 38 GCPs for the DEM covering the lower part of Inylchek Glacier and 47 GCPs for the stereo pair covering the accumulation region of Inylchek Glacier with a final RMSE of $\sim 1$ pixel. GCP coordinates and elevations were derived from Landsat 7 ETM+ scenes and the SRTM3 DEM. For processing, the frame camera model in LPS was used and the final resolution of the KH-9 DEMs was $25 \mathrm{~m}$.

ALOS PRISM and SPOT-5 were processed with four additional GCPs in order to improve the accuracy of the exterior orientation (Supplement Table S1). The automatically generated tie points (TPs) were visually checked in terms of ground objective and topographic features. In total, 120 TPs were used. The spatial resolution of the ALOS and SPOT-5
DEMs was $10 \mathrm{~m}$. Differencing of multi-temporal DEMs requires a coregistration including the removal of horizontal and vertical offsets (Pieczonka et al., 2013). We used the analytical method proposed by Nuth and Kääb (2011), which has been proven to provide robust results and to be computationally effective (Paul et al., 2015). All DEMs were bilinearly resampled to the same cell size of $30 \mathrm{~m}$. The resolution is a compromise between the possible higher resolution of $\mathrm{KH}$ 9 and SPOT-5 DEMs and the lower resolution of the SRTM DEM. The shift vectors were calculated based on selected ice-free sample regions (Fig. S3). The resulting horizontal shifts were of the order of two pixels and the z-offsets varied between $1.3 \mathrm{~m}$ and almost $20 \mathrm{~m}$ (Table S2).

\subsection{Radar penetration}

Radar penetration for the SRTM C-band in ice, firn and snow needs to be considered (Gardelle et al., 2012; Kääb et al., 2012; Mätzler and Wiesmann, 1999). A Landsat ETM+ (Level 1) scene from 18 February, which is within the time of the SRTM mission (11-20 February 2000), revealed that SIG and NIG were covered by snow. We used available ICESat GLA14 footprints to compare with SRTM3 elevation data in order to assess the penetration depth as described by Kääb et al. (2012). Six out of nine ICESat tracks covering both SIG and NIG from 2003 to 2004 were selected. We classified those footprints into glacier-free terrain, debriscovered regions (region $\mathrm{A}$ and region $\mathrm{B}$ ), bare-ice and accumulation regions (Fig. S4). Fortunately, there was an excellent track over $4300 \mathrm{~m}$ a.s.1. We eliminated the differences of the elevation change between 2000 and 2003/2004 by using the elevation change rate between the footprints acquired in 2003 and 2004. The results show a mean penetration depth of $-0.1 \pm 3.2 \mathrm{~m}$ for the glacier-free terrain; $1.3 \pm 2.9 \mathrm{~m}$ for the debris-covered region $\mathrm{A} ;-3.6 \pm 4.5 \mathrm{~m}$ for the debriscovered region B (3500-3600 m a.s.1.), where some parts are bare ice; $-4.3 \pm 2.3 \mathrm{~m}$ for debris-free parts in altitudes from 4000 to $4300 \mathrm{~m}$ a.s.1.; and $-6.8 \pm 2.1 \mathrm{~m}$ for the bare-ice parts in altitudes from 4300 to $5100 \mathrm{~m}$ a.s.1. There were no data higher than $5100 \mathrm{~m}$ a.s.1.

In addition, we compared the SRTM C-band and SRTM X-band DEMs (cf. Gardelle et al., 2012) to the radar penetration estimates based on ICESat footprints. Penetration of 
the higher-frequency X-band $(9.6 \mathrm{GHz})$ is clearly lower than of the C-band $(5.3 \mathrm{GHz})$. However, it has to be taken into account that significant penetration of $6-16 \mathrm{~m}$ for snow was reported at $10.7 \mathrm{GHz}$ for a test site in Antarctica (Surdyk, 2002). Both DEMs were resampled to $30 \mathrm{~m}$ resolution. Our results show that the mean elevation difference within $100 \mathrm{~m}$ altitude zones varies between $1.7 \mathrm{~m}$ in the lower debris-free ablation area and about $2.1-4.2 \mathrm{~m}$ for altitude within the range of $4000-5100 \mathrm{~m}$ a.s.l. The penetration depth of both the lower debris-free ablation region and the altitude between 4000 and $5100 \mathrm{~m}$ a.s.l. was $2.2-2.6 \mathrm{~m}$ lower as the depth revealed by comparing ICESat GLA to SRTM3 data. The penetration depth at $4500 \mathrm{~m}$ a.s.l. (about $7 \mathrm{~m}$ ) was also slightly lower than the estimated penetration $(9 \mathrm{~m})$ in the Ak-Shiirak Massif by using a linear method (cf. Surazakov et al., 2006) at similar altitudes. The maximum elevation difference was about $9 \mathrm{~m}$ between SRTM C-band and SRTM X-band DEMs (Fig. S5). Consequently, the penetration depth was evaluated by calculating the sum of the difference between SRTM Cband and SRTM X-band DEMs and the upper value $(2.6 \mathrm{~m})$ derived by comparing ICESat GLA to SRTM3 data. Subsequently, averaged penetration depth in each altitude zone was used to correct elevation differences. The uncertainty of the radar penetration (erp) was estimated by the standard deviation (SD) to be $1.9 \mathrm{~m}$.

\subsection{Glacier elevation change and mass balance}

The elevation change was calculated based on the areaaveraged value per $100 \mathrm{~m}$ elevation zone from DEM differencing (cf. Xu et al., 2013; Formula 2, Fig. S2). After filtering outliers caused by low image contrast (e.g. by cast shadows or bright snow) for optical data, radar shadow and layover for microwave data in each zone, the mean volume of each zone was used to calculate the elevation change (Eq. 2).

$\Delta h_{\mathrm{gl}}=\frac{\sum_{i=1}^{n} \Delta h_{i} \times s_{i}}{s_{\text {all zones }}}$,

where $i$ is the number of zones, $\Delta h_{i}$ is the mean glacier elevation change in the respective zone after radar penetration correction, $s_{i}$ is the area of each zone, $n$ is the total number of zones and $s_{\text {all }}$ zones is the total area of all zones. The distal part of the tongue of SIG, which is not covered by the SPOT5 DEM (Fig. 1), was filled with the ALOS DEM. In order to account for the different times of image acquisition of ALOS PRISM and SPOT-5, we used the elevation change per year for filling the uncovered part of the SPOT-5 DEM. A density of $850 \pm 60 \mathrm{~kg} \mathrm{~m}^{-3}$ was used to convert the volume to actual mass change (cf. Huss, 2013).

The accuracies of the final DEM differences were evaluated with regard to the vertical offset over ice-free terrain which is supposed to be stable. Outlier values were identified by $3 \sigma$ and excluded from further processing (cf. Gardelle et al., 2013; Gardner et al., 2013). Due to the glacier surge in late 1996, outliers of NIG for the periods $\sim 1975-1999$ and $\sim 1975-2007$ were defined as follows: all values larger than the sum of (1) the maximum elevation difference (which is larger than $3 \sigma$ ) in the surging region, (2) the standard deviation and (3) the mean of the elevation difference. After outlier cleaning, several obvious errors could still be detected in the accumulation regions. According to the annual snow-firn layer (the thickness was less than $275 \mathrm{~mm} \mathrm{yr}^{-1}$ ) at $6148 \mathrm{~m}$ a.s.l. on SIG from 1969 to 1989 (Aizen et al., 1997), the maximum accumulation can be inferred to be less than $9.1 \mathrm{~m}\left(275 \mathrm{~mm} \mathrm{yr}^{-1} \times 33\right.$ years $)$ for the period $\sim 1975-2007$. The maximum seasonal snow depth in February 2000 was estimated to be $9.0 \mathrm{~m}$ by comparing SRTM C-band and SRTM X-band (cf. Sect. 3.5). Hence, we considered a threshold of $20 \mathrm{~m}$ as the maximum accumulation for elevations above $4000 \mathrm{~m}$ a.s.l. and assumed that the underestimation of $2.6 \mathrm{~m}$ (cf. Sect. 3.5) was included in this value. In order to analyse the relative uncertainty of the ALOS DEM compared to the SPOT-5 DEM, we measured a profile with 342 sample points between 3050 and $3350 \mathrm{~m}$ a.s.l. on the glacier. The results revealed an uncertainty of $4.5 \mathrm{~m}$ with a standard deviation of $3.6 \mathrm{~m}$. This uncertainty from ALOS DEM included glacier elevation changes between 2006 and 2007.

The uncertainty in the differences between the two DEMs was estimated by the normalized median absolute deviation (NMAD) (expressed by $1.4826 \times \operatorname{MED}\left(\left|\widetilde{x}-x_{i}\right|\right) ; x_{i}$ : elevation difference; $\tilde{x}$ : Median) for the ice-free terrain (Table S2). Considering the radar wave penetration accuracy of $2.3 \mathrm{~m}$, the uncertainty of the DEM differences was calculated according to Eq. (3). The final mass balance uncertainty $(E)$ has been calculated considering the DEM uncertainty $(e)$, where $t$ is the observation period, $\rho_{I}$ the ice density $\left(850 \mathrm{~kg} \mathrm{~m}^{-3}\right)$, $\Delta \rho$ the ice density uncertainty $\left(60 \mathrm{~kg} \mathrm{~m}^{-3}\right), \rho_{\mathrm{w}}$ the water density $\left(999.92 \mathrm{~kg} \mathrm{~m}^{-3}\right)$ and $\varepsilon$ the uncertainty due to lack of information (Eq. 4).

$$
\begin{aligned}
& e=\sqrt{\mathrm{NMAD}^{2}+2.3^{2}} \\
& E=\frac{e \sqrt{(\Delta \rho)^{2}+\left(\rho_{I}\right)^{2}}}{t \times \rho_{\mathrm{W}}}+\varepsilon
\end{aligned}
$$

\section{Results}

\subsection{Glacier flow}

We noticed high velocities with an average flow of 100$120 \mathrm{ma}^{-1}$ (Fig. 3, between point B and point C, representing the central ablation region) for SIG towards Lake Merzbacher, while the remaining part of the debris-covered tongue (between point $\mathrm{A}$ and point $\mathrm{B}$, lower ablation region/downstream of Lake Merzbacher) has significantly lower velocities with decreasing rates and likely stagnant parts at the terminus (Fig. 3). An obvious low-flow section (less than $30 \mathrm{~m} \mathrm{a}^{-1}$ ) at point $\mathrm{B}$, upstream of the turn to Lake Merzbacher, was observed in both 2002/2003 and 
Table 3. The SIG and NIG area change between $\sim 1975$ and 2007.

\begin{tabular}{llll}
\hline Year/period & Area/area change & SIG & NIG \\
\hline$\sim 1975$ & Area $\left(\mathrm{km}^{2}\right)$ & $508.4 \pm 7.6$ & $156.6 \pm 3.3$ \\
$\sim 1975-1990$ & Area change $\left(\mathrm{km}^{2}\right)$ & $-0.1 \pm 0.1$ & $-1.2 \pm 0.1$ \\
& Area change $(\%)$ & 0.0 & -0.8 \\
& Annual area change $\left(\mathrm{km}^{2} \mathrm{a}^{-1}\right)$ & $-0.007 \pm 0.007$ & $-0.08 \pm 0.007$ \\
\multirow{2}{*}{$1990-1999$} & Area change $\left(\mathrm{km}^{2}\right)$ & $-0.5 \pm 0.1$ & $+3.7 \pm 0.1$ \\
& Area change $(\%)$ & -0.1 & +2.4 \\
& Annual area change $\left(\mathrm{km}^{2} \mathrm{a}^{-1}\right)$ & $-0.056 \pm 0.011$ & $+0.411 \pm 0.011$ \\
$1999-2007$ & Area change $\left(\mathrm{km}^{2}\right)$ & $-0.2 \pm 0.1$ & $-0.4 \pm 0.1$ \\
& Area change $(\%)$ & 0.0 & -0.3 \\
\multirow{4}{*1975-2007}{} & Annual area change $\left(\mathrm{km}^{2} \mathrm{a}^{-1}\right)$ & $-0.025 \pm 0.013$ & $-0.050 \pm 0.013$ \\
& Area change $\left(\mathrm{km}^{2}\right)$ & $-0.8 \pm 0.1$ & $+2.0 \pm 0.1$ \\
& Area change $(\%)$ & -0.2 & +1.3 \\
& Annual area change $\left(\mathrm{km}^{2} \mathrm{a}^{-1}\right)$ & $-0.025 \pm 0.003$ & $+0.063 \pm 0.003$ \\
\hline
\end{tabular}
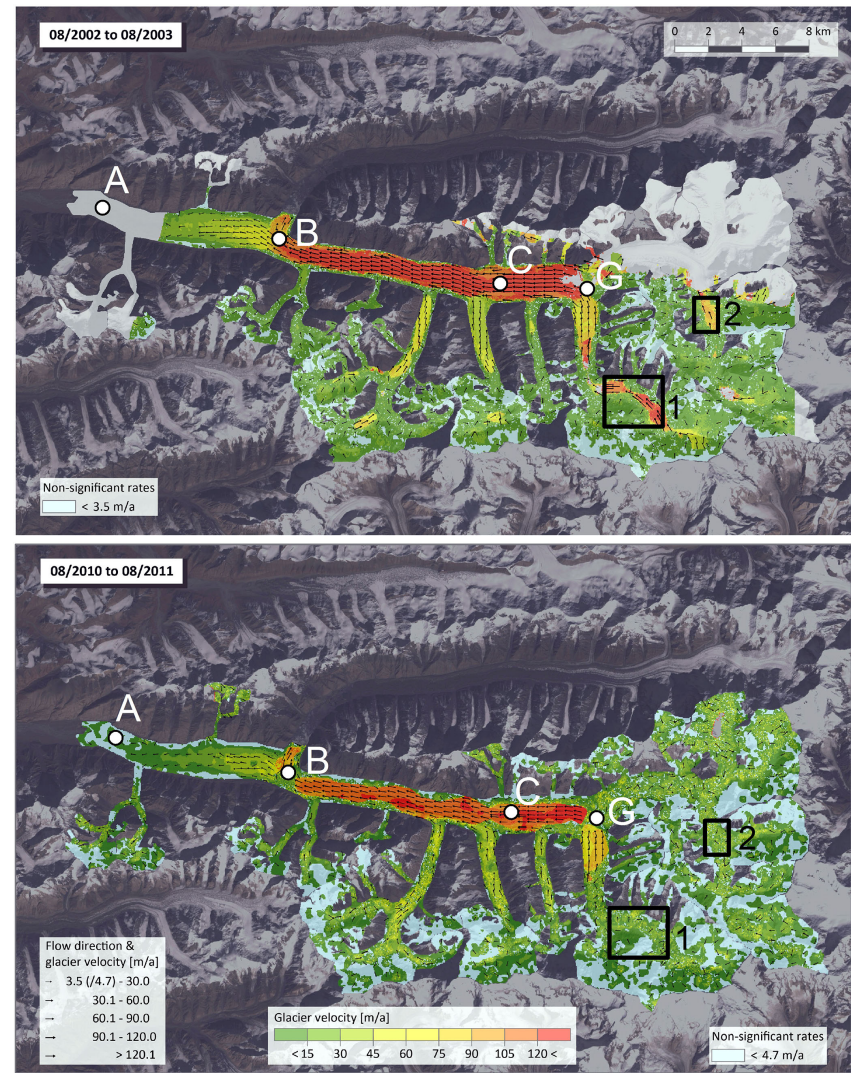

Figure 3. Mean annual flow direction and velocity of SIG in the time intervals 2002-2003 (a) and 2010-2011 (b).

2010/2011 (Fig. 3). A significant acceleration was observed from point $B$ to the lake dam. These results are in agreement with Nobakht et al. (2014).

Most tributaries have active flows until the confluence of the glacier with velocities varying typically between 30 and $60 \mathrm{ma}^{-1}$. The general patterns and velocities in main flow direction are similar for both investigated periods (2002/2003 and 2010/2011). However, comparing the velocities of 2002/2003 and 2010/2011 shows a slight deceleration for the main stream of SIG (Fig. S6). Significant deceleration of the surface velocity were found in region 1 and region 2 (cf. Fig. 3) with high velocities (more than $60 \mathrm{~m} \mathrm{a}^{-1}$ ) for the period 2002/2003 and lower velocities (less than $45 \mathrm{~m} \mathrm{a}^{-1}$ ) for the period 2010/2011.

\subsection{Glacier area change}

SIG shrank continuously during all investigated periods (Table 3). The overall area loss of SIG was $0.8 \pm 0.1 \mathrm{~km}^{2}$ $\left(0.025 \pm 0.003 \mathrm{~km}^{2} \mathrm{a}^{-1}\right)$ during $\sim 1975$ and 2007, accounting for $\sim 0.2 \%$ of its area in $\sim 1975$. NIG lost area during the period $\sim 1975-1990$ followed by a significant area increase for the consecutive period 1990-1999 (Table 3). Within this period, the glacier showed a strong advance of about $3.5 \mathrm{~km}$. The glacier shrank slightly after 1999 (Table 3). Overall, the area of the NIG increased by $2.0 \pm 0.1 \mathrm{~km}^{2}$ $\left(0.063 \pm 0.003 \mathrm{~km}^{2} \mathrm{a}^{-1}\right)$ during $\sim 1975-2007$, accounting for $\sim 1.3 \%$ of its area in $\sim 1975$ (Fig. 2; Table 3). Consequently, the area of the entire Inylchek Glacier system increased by $1.3 \pm 0.1 \mathrm{~km}^{2}(\sim 0.2 \%)$ between $\sim 1975$ and 2007.

\subsection{Glacier mass change}

The mass budget of SIG and NIG was $-0.43 \pm 0.10$ and $-0.25 \pm 0.10 \mathrm{~m}$ w.e. $\mathrm{a}^{-1}$, respectively, for the $\sim 1975-1999$ period. After 1999, the mass budget of SIG was probably less negative $\left(-0.28 \pm 0.46 \mathrm{~m}\right.$ w.e. $\left.\mathrm{a}^{-1}\right)$, while the mass budget of NIG was probably more negative $\left(-0.57 \pm 0.46 \mathrm{~m}\right.$ w.e. $\left.\mathrm{a}^{-1}\right)$. Both SIG and NIG experienced a mass loss between $\sim 1975$ and 2007, but the loss was less for NIG (Fig. 4 and Table 4). We also noted significant thinning of about $0.5-2.0 \mathrm{~m} \mathrm{a}^{-1}$ from $\sim 1975$ to 2007 for SIG close to the lake dam (Fig. 4). 


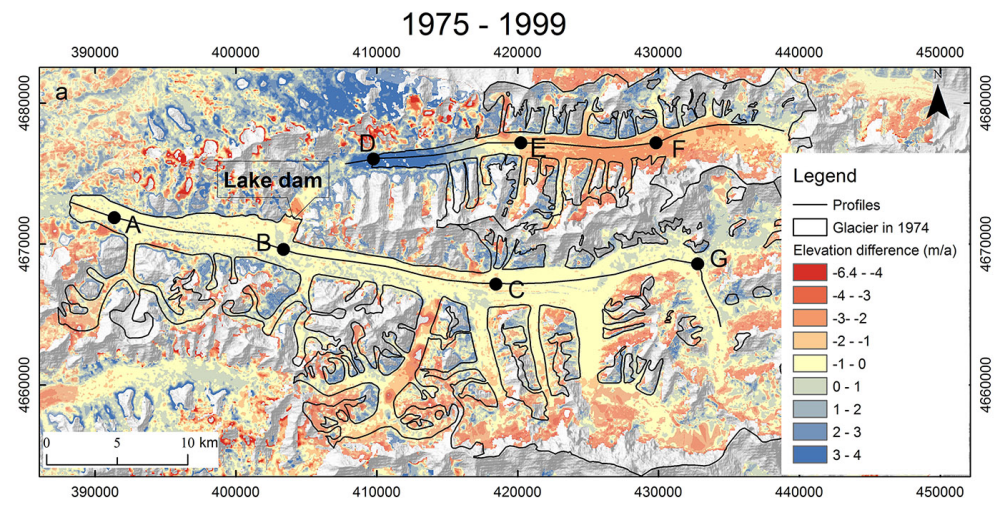

$1999-2007$

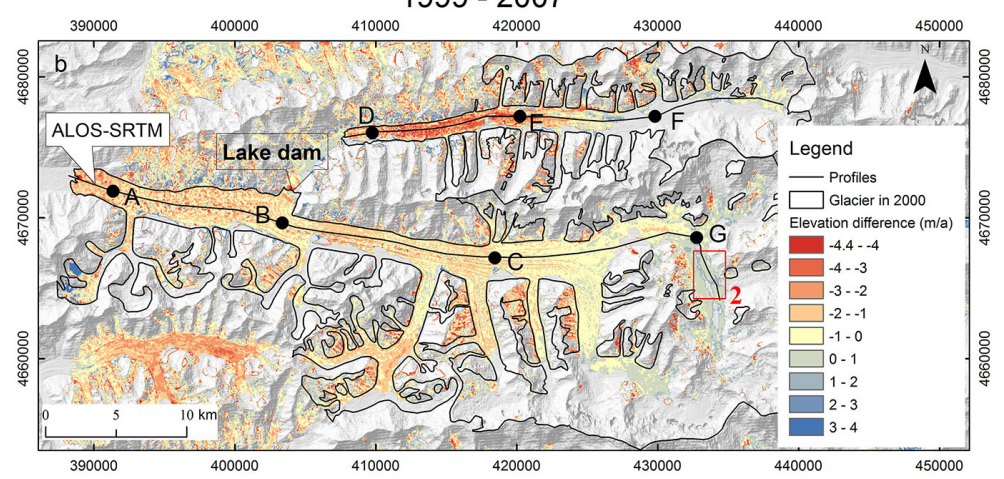

$1975-2007$

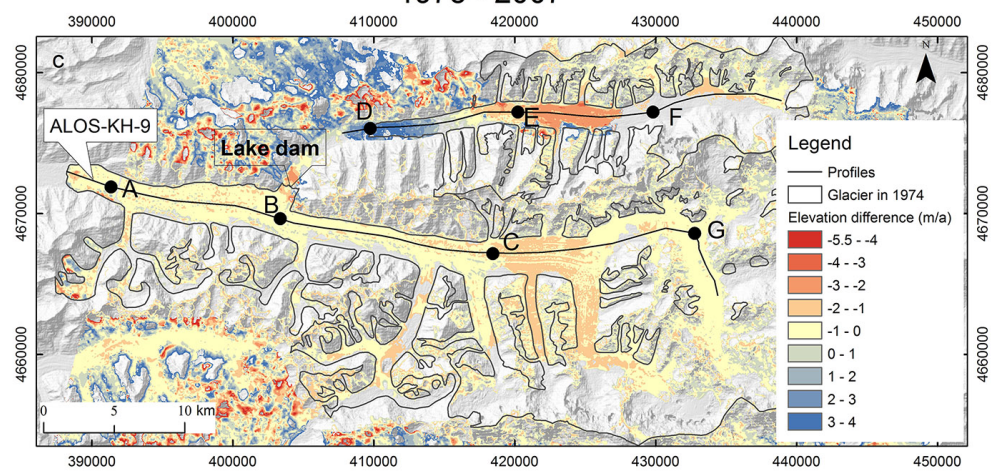

Figure 4. (a) Elevation difference of SIG and NIG between KH-9 ( 1975) and SRTM (1999); (b) elevation difference of SIG and NIG between SRTM (1999) and SPOT-5 (2007); (c) elevation difference of SIG and NIG between KH-9 ( 1975) and SPOT (2007). The altitude of points A, B, C, D, E, F and G are 3080, 3400, 3860, 3430, 3685, 4000 and $\sim 4410$ m a.s.1., respectively, derived from SRTM. Point $\mathrm{A}$ is on the edge of SPOT DEM and ALOS DEM. From the tongue of SIG to point A, the ice elevation differences are derived from KH-9-ALOS in (b) and SRTM-ALOS in (c). Point C and point E are on the boundary of KH-9 in 1974 and KH-9 in 1976; region 2 is the accumulation region of SIG in (b).

At this location, high flow velocities were observed (Fig. 3), which causes more ice to be transported (Mayer et al., 2008; $\mathrm{Ng}$ et al., 2007).

The elevation differences measured along the main flow line allow more detailed insights into the characteristics of the glaciers behaviour (Fig. 5). SIG showed a surface lowering from its terminus to point B for the periods 1975-1999 and 1999-2007 (Fig. 5). There are large variations in elevation changes between point A and B below Lake Merzbacher
(Fig. 5) where the glacier is heavily debris covered and shows low or inexistent surface flow (Fig. 3). A clear surface lowering could be observed higher up the glacier between point $\mathrm{B}$ and $\mathrm{G}$ for all investigated periods (Figs. 4 and 5). We also identified parts with no significant surface elevation changes at SIG above point C for 1975-1999 (Fig. 4a) until $\sim 37 \mathrm{~km}$ from the terminus (Fig. 5). An apparent elevation increase at a mean rate of $1-2 \mathrm{~m} \mathrm{a}^{-1}$ was observed for the period 1999-2007 in region 2 (above point G) of the accu- 
Table 4. Glacier mass changes based on area-averaged $\mathrm{d} h / \mathrm{d} t$ for period $\sim 1975-2007$.

\begin{tabular}{llrlrrr}
\hline & & $\begin{array}{l}\text { Altitude zone } \\
(\mathrm{m} \text { a.s.1. })\end{array}$ & $\begin{array}{r}\text { Area covered by } \\
\text { DEM }\left(\mathrm{km}^{2}\right)\end{array}$ & $\begin{array}{r}\text { Percentage of } \\
\text { total area }(\%)\end{array}$ & $\begin{array}{r}\text { Glacier mass changes } \\
\left(\mathrm{m} \mathrm{w.e.}^{-1}\right)\end{array}$ \\
\hline \multirow{2}{*}{ SIG } & SRTM-KH9 & $\sim 1975-1999$ & $2900-6600$ & 374.5 & 73.9 & $-0.43 \pm 0.10$ \\
& SPOT-SRTM & $1999-2007$ & $3000-6600$ & 241.7 & 47.6 & $-0.28 \pm 0.46$ \\
& SPOT-KH9 & $\sim 1975-2007$ & $2800-6600$ & 388.6 & 76.43 & $-0.42 \pm 0.11$ \\
\hline \multirow{2}{*}{ NIG } & SRTM-KH9 & $\sim 1975-1999$ & $3300-6300$ & 107.5 & 67.6 & $-0.25 \pm 0.10$ \\
& SPOT-SRTM & $1999-2007$ & $3300-6400$ & 62.7 & 39.2 & $-0.57 \pm 0.46$ \\
& SPOT-KH9 & $\sim 1975-2007$ & $3400-6600$ & 109.9 & 69.1 & $-0.30 \pm 0.11$ \\
\hline
\end{tabular}
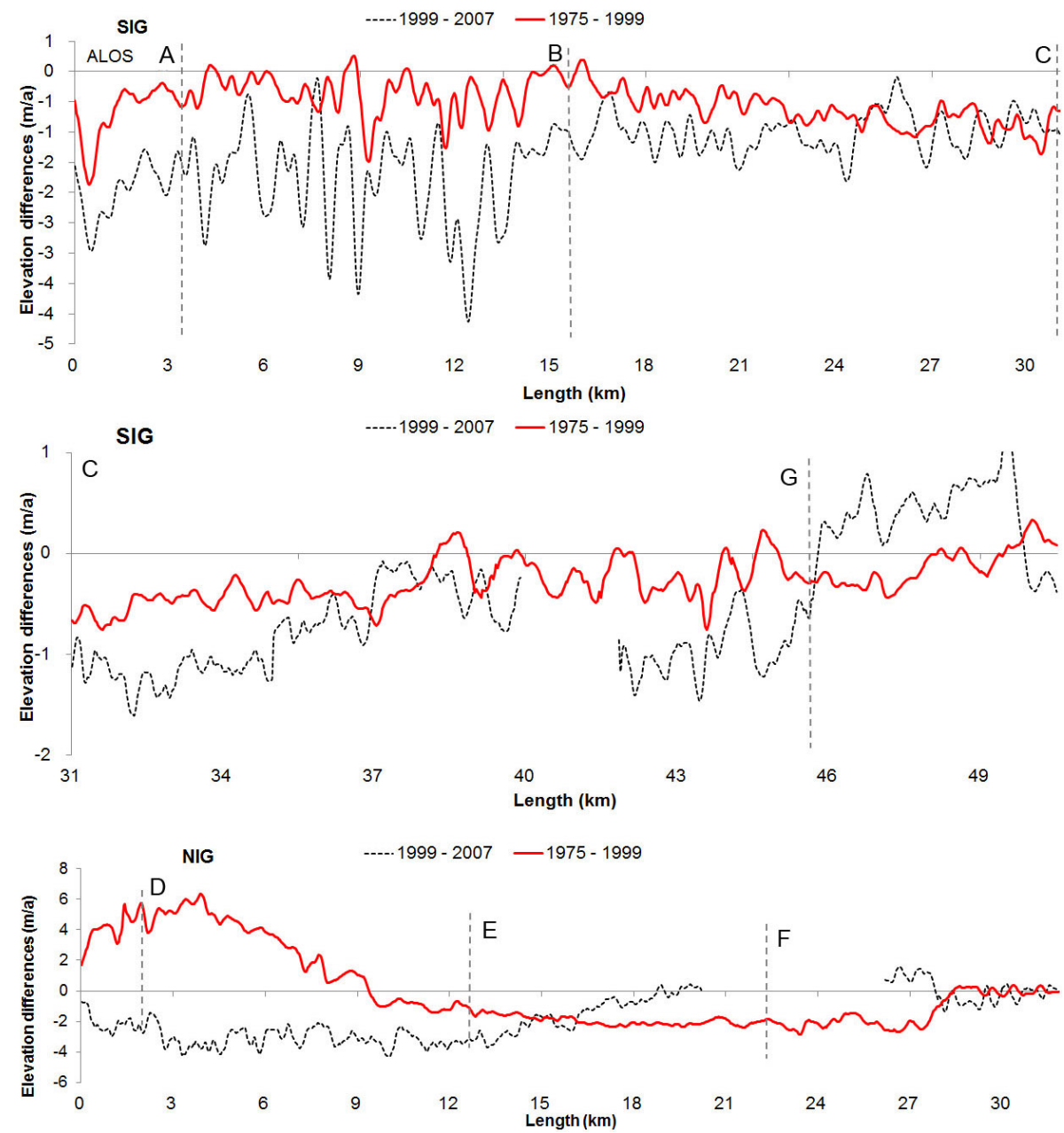

Figure 5. Longitudinal profiles of SIG and NIG for the periods 1975-1999 (KH-9-SRTM) and 1999-2007 (SRTM-SPOT). The section of ALOS PRISM between the tongue of SIG and point A was derived from SRTM-ALOS in black line.

mulation region of SIG (Fig. 4b), where decreased velocities were measured during the periods 2002-2003 and 20112012 (Fig. 3a). NIG showed a significant thickening with maximum values of $\sim 150 \mathrm{~m}$ close to the terminus (point D) for the period $\sim 1975-1999$, while the glacier rapidly thinned about $100 \mathrm{~m}$ further upwards the glacier tongue (between point $\mathrm{E}$ and F; Fig. 5 NIG). Hence, a large amount of mass was transferred from the accumulation to the ablation region, which is a typical sign of a glacier surge. After 1999, NIG showed a clear thinning throughout the tongue.

SIG experienced thinning throughout all altitude zones except at high elevations between 6300 and 6500 a.s.l. for the period $\sim 1975-1999$. The most obvious thinning was observed at $3700-4500$ and $5400-5800 \mathrm{~m}$ a.s.l. 


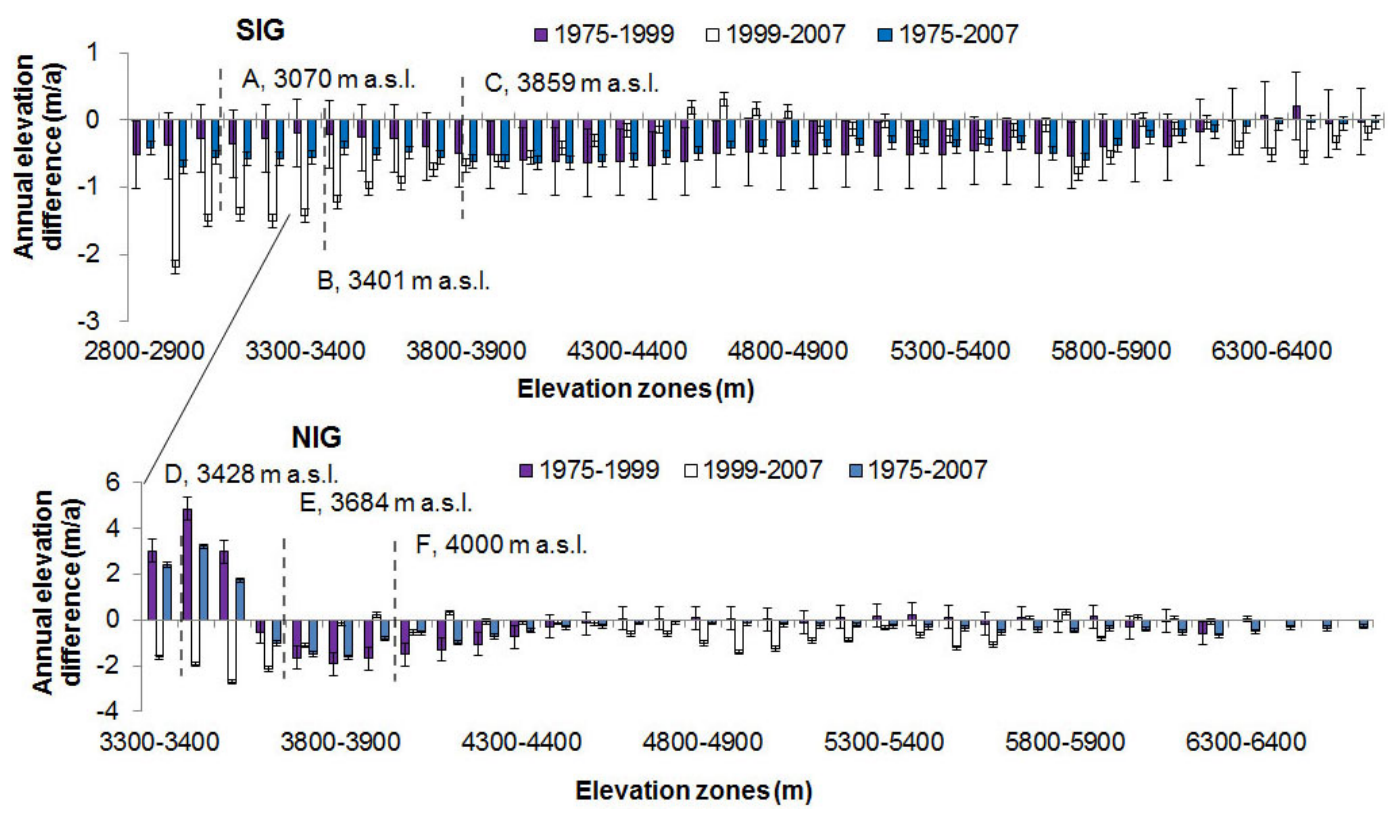

Figure 6. The mean annual elevation difference measured for the periods of 1975-1999 (KH-9-SRTM), 1999-2007 (SRTM-SPOT) and $\sim 1975-2007$ (KH-9-SPOT) along the elevation zones in the SIG and NIG. For SIG, the elevation difference in zones 2800-3000 was derived from KH-9-ALOS between $\sim 1975$ and 2006.

For the period 1999-2007, surface lowering was measured only below $4500 \mathrm{~m}$ a.s.l. with a mean rate of about $0.9 \pm 0.5 \mathrm{~m} \mathrm{a}^{-1}$. In contrast, a possible thickening with a mean rate of $0.2 \pm 0.5 \mathrm{~m} \mathrm{a}^{-1}$ was observed between 4500 and $4900 \mathrm{~m}$ a.s.l. (Fig. 6; Table S3). For the entire investigation period ( 1975-2007), the surface elevation of SIG decreased below $6500 \mathrm{~m}$ a.s.1.

\section{Discussion}

\subsection{Uncertainty}

Seasonal snow in the accumulation region and debris cover, as present in our study region, usually complicated precise glacier mapping (cf. Bolch et al., 2010; Paul et al., 2013). In order to assess our uncertainty estimate, we compared the results of the buffer method used with the uncertainty model suggested by Pfeffer et al. (2014) $(e(s)=k \times e \times \operatorname{Sp}(k=$ $3 ; e=0.039 ; p=0.7))$. The results show that the delineation uncertainty of SIG using their approach with $30 \mathrm{~m}$ according to the resolution of Landsat TM was about $9 \mathrm{~km}^{2}$. This is smaller than our estimate of about $11 \mathrm{~km}^{2}$. Hence we think our approach provides a reliable uncertainty estimate, especially as we used a larger buffer of two pixels in each image for the debris-covered parts.

One critical issue with all studies using the SRTM3 DEM for geodetic mass balance calculations is the unknown $\mathrm{C}$ band radar penetration into snow and ice. We estimated the penetration by comparing the SRTM C-band with the SRTM $\mathrm{X}$-band DEM and added an additional value derived by ICE-
Sat laser altimetry data (cf. Kääb et al., 2012). As a result, we could also consider the possible penetration of the higherfrequency X-band radar. The uncertainty for our mass balance estimation is strongly influenced by this penetration correction. The estimated mean SRTM penetration for both SIG and NIG was $4.8 \pm 1.9 \mathrm{~m}$. This is larger than the correction estimated for the Karakorum (Gardelle et al., 2013) and Hindu Kush (Kääb et al., 2012). The correction for radar penetration led to changes in mass budgets on average of $+0.17 \mathrm{~m}$ w.e. $\mathrm{a}^{-1}$ for the period $\sim 1975-1999$ and of $-0.51 \mathrm{~m}$ w.e. $\mathrm{a}^{-1}$ for the period 1999-2007.

One of the additional major uncertainties in our study is caused by the lack of information in several altitudinal zones due to data voids in the accumulation regions (Fig. S2). Pieczonka et al. (2013) used different suitable assumptions to fill the data voids in accumulation regions. In this study, the maximum, minimum and mean elevation changes observed in the accumulation regions were used to fill the voids and to evaluate the impact on the total glacier mass balance. We found that the area in those zones was too small $(0.5 \%$ above $6500 \mathrm{~m}$ a.s.l. in area) to affect the results significantly. The different assumptions led to a variation of the mass balance by only less than $0.02 \mathrm{~m} \mathrm{a}^{-1}$. This number is included in the uncertainty terms (Eq. 4).

\subsection{Glacier changes}

Our study revealed only a slight retreat of SIG during $\sim 1975$ and 2007, while a strong advance for NIG was observed between 1990 and 2000. Osmonov et al. (2013) reported an 
average shrinkage of $3.7 \pm 2.7 \%$ from 1990 to 2010 with 10 advancing glaciers in the upper Aksu Catchment. Our results are in agreement with Osmonov et al. (2013), who found shrinkage of $1.4 \%$ of Inylchek Glacier. However, they did not analyse SIG and NIG separately and did not report the NIG surge. Glacier shrinkage in outer regions of the Tian Shan, such as in northern Tian Shan (Aizen et al., 2006, Bolch, 2007; Narama et al., 2010) or the eastern/Chinese part of Tian Shan (Ding et al., 2006), was significantly larger.

Our observed velocities for SIG $\left(\sim 120 \mathrm{~m} \mathrm{a}^{-1}\right.$ for the main tongue) are in agreement with Nobakht et al. (2014) and Neelmeijer et al. (2014), who measured velocity rates of $0.3-0.4 \mathrm{~m} \mathrm{day}^{-1}\left(\sim 100-150 \mathrm{~m} \mathrm{a}^{-1}\right)$ based on ASTER and Landsat data. However we found that our observed velocities were larger than the $0.2 \mathrm{~m} \mathrm{day}^{-1}\left(\sim 75 \mathrm{~m} \mathrm{a}^{-1}\right)$ noted by Li et al. (2013) based on ALOS PALSAR data. The velocity close to Lake Merzbacher between 2002 and 2003 $\left(75-90 \mathrm{~m} \mathrm{a}^{-1}\right)$ also matches the in situ measurements (80$90 \mathrm{~m} \mathrm{a}^{-1}$ ) conducted by Mayer et al. (2008). Glacier calving could be observed for the SIG with mean velocities of up to $0.4 \mathrm{~m} \mathrm{day}^{-1}$ between 2009 and 2010 (Nobakht et al., 2014). Furthermore, the elevation changes were about -2.0 to $-0.5 \mathrm{~m} \mathrm{a}^{-1}$ for the periods $\sim 1975-1999$ and 1999-2007 near the lake dam. Flow velocities at the central ablation region of SIG (between point $\mathrm{B}$ and point $\mathrm{C}$ ) were higher than at the tongue below Lake Merzbacher (between point A and point B, Fig. 3). High velocities transport mass from upstream and offset the mass loss due to ice melt. Furthermore, the water probably also lubricates the glacier bed (Neelmeijer et al., 2014; Quincey et al., 2009). We estimate that there is a positive correlation between the lake and the high velocity (up to the lake margin), which in turn increases glacier mass loss (cf. Mayer et al., 2008).

Geodetic mass balance measurements of 12 mainly debriscovered glaciers south of Tomur Peak close to our study area revealed that most of the glaciers have been losing mass with rates between $0.08 \pm 0.15$ and $0.80 \pm 0.15 \mathrm{~m}$ w.e. $\mathrm{a}^{-1}$ for the time period 1976-2009 (Pieczonka et al., 2013). Moreover, two glaciers gained mass and one glacier (Qingbingtan Glacier No. 74) showed signs of a surge similar to NIG. The mass loss was lower during the last decade (19992009) than before 1999 (Pieczonka et al., 2013). This tendency is in line with our results for SIG where we found on average a clear mass loss during 1975-1999 followed by a decreased mass loss between 1999 and 2007. However, this represents a small difference for NIG, which showed surge-type behaviour. Existing in situ mass balance measurements in the Tian Shan also show clearly negative mass budgets since the beginning of the measurements in the 1960s (WGMS, 2013; Sorg et al., 2012). The mass balance from Kara Batkak and Tuyuksu glaciers, for instance, was -0.77 and $-0.59 \mathrm{~m}^{-}$w.e. $\mathrm{a}^{-1}$ between 1974 and 1990, respectively, and the mass balance of Tuyuksu Glacier was $-0.35 \mathrm{~m}$ w.e. $^{-1}$ from 1999-2007 (Unger-Shayesteh et al., 2013; WGMS, 2013; Cao, 1998). The tendency of Tuyuksu
Glacier mass balance in the recent period is in line with the observed mass loss for SIG for which we found an average mass loss of about $-0.43 \pm 0.10 \mathrm{~m}$ w.e. $\mathrm{a}^{-1}$ during $\sim 1975-$ 1999 followed by a mass loss of $-0.28 \pm 0.46 \mathrm{~m}$ w.e. $\mathrm{a}^{-1}$ during 1999-2007. However, the mass balance of the Urumqi Glacier No. 1 was -0.24 m w.e. $\mathrm{a}^{-1}$ during $1975-1999$ and $-0.63 \mathrm{~m}^{2}$.e. $\mathrm{a}^{-1}$ during 1999-2007 (Wang et al., 2012; WGMS, 2013). This tendency is in line with our results for NIG, for which we found on average a mass loss $\left(-0.25 \pm 0.10 \mathrm{~m}\right.$ w.e. $\left.\mathrm{a}^{-1}\right)$ during $\sim 1975-1999$ followed by an accelerating mass loss $\left(-0.57 \pm 0.46 \mathrm{~m}\right.$ w.e. $\left.\mathrm{a}^{-1}\right)$ during 1999-2007. However, both glaciers are very different in size and characteristics. Further studies based on ICESat laser altimetry pointed out that, on average, glaciers in the Tian Shan underwent clear mass loss between 2003 and 2009 $\left(-0.58 \pm 0.21 \mathrm{~m}\right.$ w.e. $\left.\mathrm{a}^{-1}\right)$ (Gardner et al., 2013). It has been noted that the elevation change for SIG is more pronounced in lower-altitude than in higher-altitude regions as seen from the two ICESat profiles (cf. Gardner et al., 2013), which is the inverse as compared with our result.

The clear thickening at the tongue of NIG and the lowering in higher altitudes (Fig. 5) together with the data of area and length change are a clear indicator for a surge event that happened between 1990 and 1999. The surge event of the NIG probably happened in late 1996 with an advance of about 2 km (Maylyudov, 1998, cit. in Häusler et al., 2011). Surging glaciers in the Tian Shan were also reported by Narama et al. (2010), Osmonov et al. (2013), Pieczonka et al. (2013), Pieczonka and Bolch (2015) and in earlier times by Dolgoushin and Osipova (1975). However, NIG surging was an atypical surging event due to the lack of surge characteristics such as areas of stretched ogives, erosion scars, transverse crevasses or breaching structures; Hodkins et al. (2009) described this phenomenon as partial surges. NIG showed a different behaviour in more or less all altitudes in comparison to SIG, which can be explained by its surge type. However, compared to elevation changes in the same altitude of SIG for the period 1999-2007, NIG experienced higher thinning at elevation of $3300-3600 \mathrm{~m}$ a.s.l. $\left(2.0 \pm 0.5 \mathrm{~m} \mathrm{a}^{-1}\right)$ than SIG $\left(1.2 \pm 0.5 \mathrm{~m} \mathrm{a}^{-1}\right)$. Consequently, the more pronounced thinning at the tongue in comparison to SIG could be due to the quiescent phase after the surge.

Both parts of the ablation regions of SIG and NIG are covered by debris below $\sim 3500 \mathrm{~m}$ a.s.l. The surface of SIG showed considerable thinning rates but also great variability for both investigated time periods of $\sim 1975-1999$ and $\sim 1975-2007$. The surface lowering is higher at the frontal part of SIG despite thick debris cover. This is in line with several other studies which found significant mass loss despite debris cover (Bolch et al., 2011; Kääb et al., 2012; Nuimura et al., 2012; Pieczonka et al., 2013). Field-based measurements in 2005 of moraine thickness and ablation rates on the SIG revealed a dependency of ablation upon debris thickness with ablation rates from 2.8 to $6.7 \mathrm{~cm} \mathrm{day}^{-1}$ with a mean of $4.4 \mathrm{~cm} \mathrm{day}^{-1}$ (Hagg et al., 2008). The lower velocities and 
even immobility downstream of Lake Merzbacher indicate that there was little mass supplied from upstream. Therefore, the significant mass loss in the debris-covered region can be explained by the influence of backwasting at ice cliffs and melting at supraglacial ponds (Fujita and Sakai, 2009; Han et al., 2010; Juen et al., 2014) but likely also as a consequence of little mass contribution from the accumulation region due to low flow velocities or even stagnancy (Benn et al., 2012; Bolch et al., 2012; Quincey et al., 2009; Schomacker, 2008).

Measurements at the TS (3614 ma.s.1.), located $120 \mathrm{~km}$ west of SIG, revealed increasing temperature and decreasing precipitation during the ablation season (May-September) for the period 1970-1996. During the ablation season for the period of 1997-2009, a decreasing temperature and a slight decreasing precipitation was measured (Krysanova et al., 2015; Osmonov et al., 2013; Reyers et al., 2013). This is in disagreement with the observed climate change in the Tarim Basin, where temperature increased after 1985 and annual precipitation increased after 1980 (Chen et al., 2009; Shi et al., 2006). Hence, the observed significant glacier mass loss between $\sim 1975$ and 1999 is most likely a consequence of the ablation season warming and precipitation decrease which led to an accelerated melting and less accumulation. The increased mass loss of NIG between 1999 and 2007 can be explained by high mass loss at the tongue of NIG as a result of strong advance in the mid-1990s.

\section{Conclusions}

We investigated glacier velocity, glacier area, surface elevation and mass changes of the Southern and Northern Inylchek Glacier for the period 1975-2007 based on multitemporal space-borne data sets such as KH-9 Hexagon, Landsat and SPOT-5 HRG data. Our results show that SIG has a velocity of about $100 \mathrm{ma}^{-1}$ for large parts upstream of Lake Merzbacher with a main flow direction towards Lake Merzbacher and clearly lower velocities with stagnant parts downstream of the lake. Decreasing velocities at the SIG tongue were found when comparing surface displacements in 2002/2003 to 2010/2011. In general, area of the SIG decreased in the $\sim 1975-2007$ period. However, a surge of NIG before 1999 caused an overall area increase of $2.0 \pm 0.1 \mathrm{~km}^{2}(\sim 1.3 \%)$ between $\sim 1975$ and 2007 . The generated DEMs from $\sim 1975$ and 2007 were of good quality though partially missing information in the accumulation regions caused higher uncertainties. The results showed that the mass balance of both SIG and NIG was negative from $\sim 1975$ to 2007 . However, the amplitude of both glaciers' mass loss was different. For SIG, decreased mass loss in the most recent decade was observed with an overall mass balance of $-0.42 \pm 0.11 \mathrm{~m}$ w.e. $\mathrm{a}^{-1}$ between $\sim 1975$ and 2007. For NIG, on the other hand, increased mass loss could be found since 1999 and a mass balance of about $-0.30 \pm 0.11 \mathrm{~m}$ w.e. $\mathrm{a}^{-1}$ was measured for the entire investi- gated period. Despite thick debris cover, surface lowering is highest at the distal part of the tongue of SIG where also low velocities are prevailing. The thinning at the lake dam was also large with a high flow velocity until the calving front, likely caused by calving events into Lake Merzbacher. Thus, glacier thinning and glacier flow are significantly influenced by the lake.

\section{The Supplement related to this article is available online at doi:10.5194/tc-9-703-2015-supplement.}

Author contributions. The concept of this study was developed by D. H. Shangguan and T. Bolch. The digital elevation models were generated by D. H. Shangguan and T. Pieczonka. The glacier surface velocities were calculated by M. Kröhnert. D. H. Shangguan performed the data analysis and wrote the draft of the paper. D. H. Shangguan, T. Bolch and all other authors were involved in paper writing or supported this work.

Acknowledgements. This work was supported by the Ministry of Science and Technology of the People's Republic of China (grant 2013CBA01808), State Key Laboratory of Cryospheric Sciences (SKLCS-ZZ-2012-00-02), the National Natural Science Foundation of China (grants 41271082 and 41030527), the CAS Strategic Priority Research Program-Climate Change: Carbon Budget and Relevant Issue (grant no. XDA05090302), German Research Foundation (Deutsche Forschungsgemeinschaft, DFG, code BO 3199/2-1), and the German Ministry of Education and Science (BMBF: Code 01 LL 0918 B). The China Scholarship Council supported the research stay of the first author at the University of Zurich. We thank the group of B. Moldobekov from the Central Asian Institute for Applied Geosciences (CAIAG) for supporting our field work in 2010 and 2012 and J. Bodart for proof reading. We also thank DLR for free access to SRTM Xband data and USGS for free access to SRTM C-band and Landsat data. ASTER GDEM and SRTM are a product of METI and NASA.

Edited by: J. O. Hagen

\section{References}

Aizen, V. B., Aizen, E., Dozier, J., and Melack, J. M.: Glacier regime of the highest Tien Shan mountain, Pobeda-Khan Tengry Massif, J. Glaciol., 43, 503-512, 1997.

Aizen, V. B., Kuzmichenok, V. A., Surazakov, A. B., and Aizen, E. M.: Glacier changes in the central and northern Tien Shan during the last 140 years based on surface and remote-sensing data, Ann. Glaciol., 43, 202-213, 2006.

Aizen, V. B., Aizen, E. M., and Kuzmichonok, V. A.: Glaciers and hydrological changes in the Tien Shan: simulation and prediction, Environ. Res. Lett., 2, 045019, doi:10.1088/17489326/2/4/045019, 2007. 
Benn, D. I., Bolch, T., Hands, K., Gulley, J., Luckman, A., Nicholson, L. I., Quincey, D., Thompson, S., Toumi, R., and Wiseman, S.: Response of debris-covered glaciers in the Mount Everest region to recent warming, and implications for outburst flood hazards, Earth-Sci. Rev., 114, 156-174, 2012.

Berthier, E., Arnaud, Y., Kumar, R., Ahmad, S., Wagnon, P., and Chevallier, P.: Remote sensing estimates of glacier mass balances in the Himachal Pradesh (Western Himalaya, India), Remote Sens. Environ., 108, 327-338, 2007.

Berthier, E., Schiefer, E., Clarke, G. K. C., Menounos, B., and Remy, F.: Contribution of Alaskan glaciers to sea-level rise derived from satellite imagery, Nat. Geosci., 3, 92-95, 2010.

Bolch, T.: Climate change and glacier retreat in northern Tien Shan (Kazakhstan/Kyrgyzstan) using remote sensing data, Glob. Planet. Change, 56, 1-12, 2007.

Bolch, T., Menounos, B., and Wheate, R.: Landsat-based inventory of glaciers in western Canada, 1985-2005, Remote Sens. Environ., 114, 127-137, 2010.

Bolch, T., Pieczonka, T., and Benn, D. I.: Multi-decadal mass loss of glaciers in the Everest area (Nepal Himalaya) derived from stereo imagery, The Cryosphere, 5, 349-358, doi:10.5194/tc-5349-2011, 2011.

Bolch, T., Kulkarni, A., Kääb, A., Huggel, C., Paul, F., Cogley, J. G., Frey, H., Kargel, J. S., Fujita, K., Scheel, M., Bajracharya, S., and Stoffel, M.: The state and fate of Himalayan glaciers, Science, 336, 310-314, 2012.

Bouillon, A., Bernard, M., Gigord, P., Orsoni, A., Rudowski, V., and Baudoin, A.: SPOT 5 HRS geometric performances: Using block adjustment as a key issue to improve quality of DEM generation, ISPRS J. Photogramm. Remote Sens., 60, 134-146, 2006.

Cao, M. S.: Detection of abrupt changes in glacier mass balance in the Tien Shan Mountains, J. Glaciol., 44, 352-358, 1998.

Chen, Y., Xu, C., Hao, X., Li, W., Chen, Y., Zhu, C., and Ye, Z.: Fifty-year climate change and its effect on annual runoff in the Tarim River Basin, China, Quaternary Internat., 208, 53-61, 2009.

Ding, Y. J., Liu, S. Y., Li, J., and Shangguan, D. H.: The retreat of glaciers in response to recent climate warming in western China, Ann. Glaciol., 43, 97-105, 2006.

Dolgoushin, L. D. and Osipova, G. B.: Glacier surges and the problem of their forecasting. Proc. Snow and Ice Symposium, Moscow, 104, 292-304, 1975.

Fujita, K., Sakai, A., Nuimura, T., Yamaguchi, S., and Sharma, R. R.: Recent changes in Imja Glacial Lake and its damming moraine in the Nepal Himalaya revealed by in situ surveys and multi-temporal ASTER imagery, Environ. Res. Lett., 4, 045205, doi:10.1088/1748-9326/4/4/045205, 2009.

Gardelle, J., Berthier, E., and Arnaud, Y.: Impact of resolution and radar penetration on glacier elevation changes computed from DEM differencing, J. Glaciol., 58, 419-422, 2012.

Gardelle, J., Berthier, E., Arnaud, Y., and Kääb, A.: Region-wide glacier mass balances over the Pamir-Karakoram-Himalaya during 1999-2011, The Cryosphere, 7, 1263-1286, doi:10.5194/tc7-1263-2013, 2013.

Gardner, A. S., Moholdt, G., Cogley, J. G., Wouters, B., Arendt, A. A., Wahr, J., Berthier, E., Hock, R., Pfeffer, W. T., Kaser, G., Ligtenberg, S. R. M., Bolch, T., Sharp, M. J., Hagen, J. O., van den Broeke, M. R., and Paul, F.: A Reconciled Estimate of
Glacier Contributions to Sea Level Rise: 2003 to 2009, Science, 340, 852-857, 2013.

Glazirin, G. E.: A century of investigations on outbursts of the ice-dammed lake Merzbacher(central Tien Shan), Austr. J. Earth Sci., 103, 171-178, 2010.

Gorokhovich, Y. and Voustianiouk, A.: Accuracy assessment of the processed SRTM-based elevation data by CGIAR using field data from USA and Thailand and its relation to the terrain characteristics, Remote Sens. Environ., 104, 409-415, 2006.

Hagg, W., Mayer, C., Lambrecht, A., and Helm, A.: Sub-debris melt rates on southern Inylchek Glacier, Central Tian Shan., Geogr. Ann., 90A, 55-63, 2008.

Han, H., Wang, J., Wei, J., and Liu, S.: Backwasting rate on debriscovered Koxkar glacier, Tuomuer Mountain, China, J. Glaciol., 56, 287-296, 2010.

Häusler, H., Scheibz, J., Leber, B., Kopecny, A., Echtler, H., Wetzel, H.-U., and Moldobekov, B.: Results from the 2009 geoscientific expedition to the Inylchek glacier, Central Tien Shan (Kyrgyzstan), Austr. J. Earth Sci., 104, 47-57, 2011.

Huss, M.: Density assumptions for converting geodetic glacier volume change to mass change, The Cryosphere, 7, 877-887, doi:10.5194/tc-7-877-2013, 2013

Jarvis, A., Reuter, H. I., Nelson, A., and Guevara, E.: Hole-filled SRTM for the globe Version 4, available from the CGIAR-CSI SRTM 90 m Database (http://srtm.csi.cgiar.org), 2008.

Juen, M., Mayer, C., Lambrecht, A., Haidong, H., and Shiyin, L.: Impact of varying debris cover thickness on ablation: a case study for Koxkar glacier in the Tien Shan, The Cryosphere, 8, 377-386, doi:10.5194/tc-8-377-2014, 2014.

Kääb, A., Berthier, E., Nuth, C., Gardelle, J., and Arnaud, Y.: Contrasting patterns of early twenty-first-century glacier mass change in the Himalayas, Nature, 488, 495-498, 2012.

Kotlakov, V. M.: World atlas of snow and ice resources, Institute of Geography, Russian Academy of Science, Moscow, 371 pp. 1997.

Krysanova, V., Wortmann, M., Bolch, T., Merz, B., Duethmann, D., Walter, J., Huang, S., Tong, J., Buda, S., and Kundzewicz, Z. W.: Analysis of current trends in climate parameters, river discharge and glaciers in the Aksu River basin (Central Asia), Hydrol. Sci. J., 60, 566-590, doi:10.1080/02626667.2014.925559, 2015.

Leprince, S., Barbot, S., Ayoub, F., and Avouac, J. P.: Automatic and precise orthorectification, coregistration, and subpixel correlation of satellite images, application to ground deformation measurements, IEEE Trans. Geosci. Remote Sens., 45, 1529_ 1558, 2007.

Li Jia, L. Z.-W., Wang Chang-Cheng, Zhu Jian-Jun, and Ding XiaoLi: Using SAR offset-tracking approach to estimate surface motion of the South Inylchek Glacier in Tianshan, Chin. J. Geophys., 56, 1226-1236, 2013.

Li, X., Cheng, G., Jin, H., Kang, E., Che, T., Jin, R., Wu, L., Nan, Z., Wang, J., and Shen, Y.: Cryospheric change in China, Glob. Planet. Change, 62, 210-218, 2008.

Lifton, N., Beel, C., Hättestrand, C., Kassab, C., Rogozhina, I., Heermance, R., Oskin, M., Burbank, D., Blomdin, R., Gribenski, N., Caffee, M., Goehring, B. M., Heyman, J., Ivanov, M., Li, Y., Li, Y., Petrakov, D., Usubaliev, R., Codilean, A. T., Chen, Y., Harbor, J., and Stroeven, A. P.: Constraints on the late Quaternary glacial history of the Inylchek and Sary-Dzaz valleys from 
in situ cosmogenic ${ }^{10} \mathrm{Be}$ and ${ }^{26} \mathrm{Al}$, eastern Kyrgyz Tian Shan, Quaternary Sci. Rev., 101, 77-90, 2014.

Liu, S. Y., Ding, Y. J., Shangguan, D. H., Zhang, Y., Li, J., Han, H. D., Wang, J., and Xie, C. W.: Glacier retreat as a result of climate warming and increased precipitation in the Tarim river basin, northwest China, Ann. Glaciol., 43, 91-96, 2006.

Mao, W. Y., Chen, C., Duan, J. J., Su, H. C., Wang, S. F., Wang, J., and Ge F. Y.: Streamflow regime of four source streams and mainstream of Tarim River, Xinjiang, in 2000, J. Glaciol. Geocryol., 26, 488-495, 2004.

Mätzler, C. and Wiesmann, A.: Extension of the Microwave Emission Model of Layered Snowpacks to Coarse-Grained Snow, Remote Sens. Environ., 70, 317-325, 1999.

Mayer, C., Hagg, W., Lambrecht, A., Helm, A., and Scharrer, K.: Post-drainage ice dam response at Lake Merzbacher, Inylchek glacier, Kyrgyzstan, Geograf. Ann., 90, 87-96, 2008.

Narama, C., Kääb, A., Duishonakunov, M., and Abdrakhmatov, K.: Spatial variability of recent glacier area changes in the Tien Shan Mountains, Central Asia, using Corona ( 1970), Landsat $(\sim 2000)$, and ALOS ( 2007) satellite data, Global Planet. Change, 71, 42-54, 2010.

Neelmeijer, J., Motagh, M., and Wetzel, H.-U.: Estimating Spatial and Temporal Variability in Surface Kinematics of the Inylchek Glacier, Central Asia, using TerraSAR-X Data, Remote Sens., 6, 9239-9259, 2014.

Ng, F., Liu, S., Mavlyudov, B., and Wang, Y.: Climateic control on the peak discharge of glacier outburst floods, Geophys. Res. Lett., 34, L21503, doi:10.1029/2007GL0314, 2007.

Nobakht, M., Motagh, M., Wetzel, H.-U., Roessner, S., and Kaufmann, H.: The Inylchek Glacier in Kyrgyzstan, Central Asia: Insight on Surface Kinematics from Optical Remote Sensing Imagery, Remote Sens., 6, 841-856, 2014.

Nuimura, T., Fujita, K., Yamaguchi, S., and Sharma, R. R.: Elevation changes of glaciers revealed by multitemporal digital elevation models calibrated by GPS survey in the Khumbu region, Nepal Himalaya, 1992-2008, J. Glaciol., 58, 648-656, 2012.

Nuth, C. and Kääb, A.: Co-registration and bias corrections of satellite elevation data sets for quantifying glacier thickness change, The Cryosphere, 5, 271-290, doi:10.5194/tc-5-271-2011, 2011.

Osmonov, A., Bolch, T., Xi, C., Kurban, A., and Guo, W.: Glacier characteristics and changes in the Sary-Jaz River Basin (Central Tien Shan, Kyrgyzstan) 1990-2010, Remote Sens. Lett., 4, 725734, 2013.

Paul, F. and Haeberli, W.: Spatial variability of glacier elevation changes in the Swiss Alps obtained from two digital elevation models, Geophys. Res. Lett., 35, L21512, doi:10.1029/2008g1034718, 2008.

Paul, F., Barrand, N. E., Berthier, E., Bolch, T., Casey, K., Frey, H., Joshi, S. P., Konovalov, V., Bris, P. L., Molg, N., NOsenko, G., Nuth, C., Pope, A., Racoviteanu, A., Rastner, P., Raup, B., and Scharrer, K.: On the accuracy of glacier outlines derived from remote-sensing data, Ann. Glaciol., 54, 171-182, doi:10.3189/2013AoG63A296, 2013.

Paul, F., Bolch, T., Kääb, A., Nagler, T., Nuth, C., Scharrer, K., Shepherd, A., Strozzi, T., Ticconi, F., Bhambri, R., Berthier, E., Bevan, S., Gourmelen, N., Heid, T., Jeong, S., Kunz, M., Lauknes, T. R., Luckman, A., Merryman, J., Moholdt, G., Muir, A., Neelmeijer, J., Rankl, M., VanLooy, J., and Van Niel, T.: The glaciers climate change initiative: Methods for creating glacier area, elevation change and velocity products, Remote Sens. Environ., in press, doi:10.1016/j.rse.2013.07.043, 2015.

Pfeffer, W. T., Arendt, A. A., Bliss, A., bolch, T., COgley, J. G., Gardner, A. S., Hagen, J.-O., Hock, R., Kaser, G., Kienholz, C., Miles, E. S., Moholdt, G., Molg, N., Paul, F., Radic, V., Rastner, P., Raup, B. H., Rich, J., Sharp, M. J., and Consortium, T. R.: The Randolph Glacier Inventory: a globally complete inventory of glaciers, J. Glaciol., 60, 537-552, 2014.

Pressel, P.: Meeting the Challenge: The Hexagon KH-9 Reconnaissance Satellite. American Institute of Aeronautics and Astronautics, Inc., Reston, Virginia, 2013.

Piao, S., Ciais, P., Huang, Y., Shen, Z., Peng, S., Li, J., Zhou, L., Liu, H., Ma, Y., Ding, Y., Friedlingstein, P., Liu, C., Tan, K., Yu, Y., Zhang, T., and Fang, J.: The impacts of climate change on water resources and agriculture in China, Nature, 467, 43-51, doi:10.1038/nature09364, 2010.

Pieczonka, T. and Bolch, T.: Region-wide glacier mass budgets and area changes for the Central Tien Shan between 1975 and 1999 using Hexagon KH-9 imagery, Global and Planetary Change, 128, 1-13, 2015.

Pieczonka, T., Bolch, T., and Buchroithner, M.: Generation and evaluation of multitemporal digital terrain models of the Mt. Everest area from different optical sensors, Isprs J. Photogramm. Remote Sens., 66, 927-940, 2011.

Pieczonka, T., Bolch, T., Wei, J., and Liu, S.: Heterogeneous mass loss of glaciers in the Aksu-Tarim Catchment (Central Tien Shan) revealed by 1976 KH-9 Hexagon and 2009 SPOT-5 stereo imagery, Remote Sens. Environ, 130, 233-244, 2013.

Quincey, D. J., Copland, L., Mayer, C., Bishop, M., Luckman, A., and Belo, M.: Ice velocity and climate variations for Baltora Glacier, Pakistan, J. Glaciol., 55, 1061-1071, 2009.

Reyers, M., Pinto, J. G., and Paeth, H.: Statistical-dynamical downscaling of present day and future precipitation regimes in the Aksu River Catchment in Central Asia, Global Planet. Change, 107, 36-49, 2013.

Rignot, E., Echelmeyer, K., and Krabill, W.: Penetration depth of interferometric synthetic-aperture radar signals in snow and ice, Geophys. Res. Lett., 28, 3501-3504, 2001.

Schomacker, A.: What controls dead-ice melting under different climate conditions? A discussion, Earth-Sci. Rev., 90, 103-113, 2008.

Shen, Y. P., Wang, G. Y., Ding, Y. J., Mao, W. Y., Liu, S. Y., Wang, S. D., and Duishen, M. M.: Changes in Glacier Mass Balance in Watershed of Sary Jaz-Kumarik Rivers of Tianshan Mountains in 1957-2006 and Their Impact on Water Resources and Trend to End of the 21th Century, J. Glaciol. and Geocryol., 31, 792-801, 2009 (in Chinese with English abstract).

Shi, Y., Shen, Y., Kang, E., Li, D., Ding, Y., Zhang, G., and Hu, R.: Recent and future climate change in northwest China, Clim. Change, 80, 379-393, doi:10.1007/s10584-006-9121-7, 2006.

Shortridge, A., and Messina, J.: Spatial structure and landscape associations of SRTM error, Remote Sens. Environ., 115, 15761587, 2011.

Sorg, A., Bolch, T., Stoffel, M., Solomina, O., and Beniston, M.: Climate change impacts on glaciers and runoff in Tien Shan (Central Asia), Nat. Clim. Change, 2, 725-731, 2012.

Surazakov, A. B. and Aizen, V. B.: Estimating volume change of mountain glaciers using SRTM and Map-Based Topographic data, IEEE Trans. Geosci. Remote Sens., 44, 2991-2994, 2006. 
Surdyk, S.: Using microwave brightness temperature to detect short-term surface air temperature changes in Antarctica: An analytical approach, Remote Sens. Environ., 80, 256-271, 2002.

Takaku, J., Futamura, N., Iijima, T., Tadono, T., Shimada, M., and Shibasaki, R.: High resolution DEM generation from ALOS PRISM data - simulation and evaluation, Geoscience and Remote Sensing Symposium, 2004,

Toutin, T.: Generation of DSMs from SPOT-5 in-track HRS and across-track HRG stereo data using spatiotriangulation and autocalibration, Isprs J. Photogramm. Remote Sens., 60, 170-181, 2006.

Uchiyama, Y., Honda, M., Mizuta, Y., Otsuka, K., Ishizeki, T., Okatani, T., and Tamura, E.: Revising 1:25000-Scale topographic maps using ALOS/PRISM Imagery, Bull. Geogr. Survey Inst., 56, 1-15, 2008.

Unger-Shayesteh, K., Vorogushyn, S., Farinotti, D., Gafurov, A., Duethmann, D., Mandychev, A., and Merz, B.: What do we know about past changes in the water cycle of Central Asian headwaters? A review, Global Planet. Change, 110, 4-25, 2013.

USGS: Shuttle Radar Topography Mission, 3 Arc Second scene, Unfilled finished, Global Land Cover Facility, University of Maryland, College Park, Maryland, February 2000, 2006.
Wang, W., Li, Z., Zhang, G., and Li, X.: The processes and characteristics of mass balance on the Urumqi Glacier No.1 during 1958-2009, Sci. Cold Arid Reg., 4, 505-513, 2012.

WGMS: Glacier Mass Balance Bulletin No. 12 (2010-2011), in: ICSU (WDS)/IUGG (IACS)/UNEP/UNESCO/WMO. World Glacier Monitoring Service, edited by: Zemp, M., Nussbaum, S. U., Naegeli, K., Gärtner-Roer, I., Paul, F., Hoelzle, M., and Haeberli, W., Zurich, doi:10.5904/wgms-fog-2013-11, 2013.

$\mathrm{Xu}$, J., Liu, S., Zhang, S., Guo, W., and Wang, J.: Recent Changes in Glacial Area and Volume on Tuanjiefeng Peak Region of Qilian Mountains, China, PLoS ONE, 8, e70574, doi:10.1371/journal.pone.0070574, 2013.

Yang, L., Meng, X., and Zhang, X.: SRTM DEM and its application advances, Internat. J. Remote Sens., 32, 3875-3896, doi:10.1080/01431161003786016, 2011.

Zemp, M., Thibert, E., Huss, M., Stumm, D., Rolstad Denby, C., Nuth, C., Nussbaumer, S. U., Moholdt, G., Mercer, A., Mayer, C., Joerg, P. C., Jansson, P., Hynek, B., Fischer, A., Escher-Vetter, H., Elvehøy, H., and Andreassen, L. M.: Reanalysing glacier mass balance measurement series, The Cryosphere, 7, 12271245, doi:10.5194/tc-7-1227-2013, 2013. 